\title{
SOME NEW LONGICORN BEETLES FROM BRITISH HONDURAS
}

\author{
By E. GoRTON LINSLEY \\ Oakland, California
}

The new species described below were noted among some miscellaneous Cerambycidæ from British Honduras, very kindly sent to me for study by Mr. Lionel Lacey of New Rochelle, New York.

Protaneflus Linsley, new genus

Elongate, parallel, subcylindrical. Head concave between the antennæ; maxillary palpi longer than labial, last segment slightly triangular; eyes very convex, coarsely granulated; antennæ longer than the body ( $\hat{o})$, twelve-segmented; scape stout, subcylindrical, segments six to twelve flattened, serrate, carinate, segments three to seven spinose at apex. Prothorax cylindrical, slightly longer than broad. Elytra scarcely more than three times as long as broad; apices bispinose. Prosternum narrow between the coxæ; mesosternum rather broad. Anterior coxal cavities feebly angulated externally ; intermediate coxal cavities closed behind. Metasternal epsterna very narrow, slightly wider at base and apex. Legs long, slender; tibiæ feebly carinate on outer side.

Genotype: Protaneflus pubescens n. sp.

A genus related to Aneflus and Axestinus, but differing from these in the densely pubescent body and very narrow metathoracic episterna. From the former it may be further distinguished by the twelve-segmented antennæ ( $\hat{o})$, and from the latter by the spinose antennal segments.

Protaneflus pubescens Linsley, new species

Piceous, very densely clothed with short, white, recumbent pubescence. Head rather coarsely, closely punctured; antennæ densely clothed with short, white pubescence, 
sparsely ciliate at apex of segments. Prothorax transversely rugose, coarsely, densely punctured, densely pubescent. Scutellum white. Elytra coarsely and moderately closely punctured, clothed with recumbent, white pubescence intermixed with scattered, suberect hairs. Legs and ventral surface densely clothed with white pubescence. Length 31 $\mathrm{mm}$; breadth $6.5 \mathrm{~mm}$.

Holotype male, a unique taken at Punta Gorda, British Honduras, in June 1932, by Mr. J. J. White.

This fine species is rather suggestive of Aneflus cylindricollis Bates, but may be easily distinguished by the dense, white pubescence, twelve-segmented antennæ ( 0 ), and narrow metathoracic episterna.

Stizocera laceyi Linsley, new species

Elongate, subparallel, rufo-testaceous, shining, sparsely clothed with erect pale hairs. Head with scattered coarse punctures; antennæ attaining the middle of the elytra ( $q$ ), carinate, segments three to seven spinose at apex; punctation irregular; pubescence short, sparse, intermixed with flying hairs along inner side and at apex of segments. Prothorax slightly longer than broad, coarsely but not closely punctured, clothed with scattered, erect, pale hairs. Scutellum densely pubescent. Elytra nearly four times as long as broad, yellowish-testaceous; punctation moderately coarse, not dense; pubescence pale, sparse, suberect; apex piceous, bispinose. Legs slender, clothed with long, suberect, yellowish hairs ; femora bispinose at apex, the spines piceous. Ventral surface shining, sparsely, finely punctured, sparsely clothed with suberect, yellowish pubescence. Length 22 $\mathrm{mm}$; breadth $5 \mathrm{~mm}$.

Holotype female, captured at Punta Gorda, British Honduras, June 1932, by Mr. J. J. White.

A moderately large, shining, rufo-testaceous species with yellowish-testaceous elytra which become piceous at the apex. It is related to $S$. armata Serv. from Brazil, but in addition to differences in color, may be easily distinguished from that species by the short antennæ, which in the female attain only the middle of the elytra (in S. armata o the antennæ are slightly longer than the body), and by the bispi- 
nose intermediate and posterior femora (in S. armata only the posterior femora are spinose at apex).

Stizocera aliena Linsley, new species

Elongate, slender, reddish-brown, shining. Head coarsely, closely punctured; antennæ attaining apical one-third of elytra ( $\hat{b})$, middle of elytra ( $q)$, carinate, ciliate, segments three to five spinose at apex. Prothorax about onefourth longer than broad, coarsely, closely punctured, sparsely clothed with erect, pale pubescence. Scutellum densely pubescent. Elytra four times as long as broad; punctation coarse; pubescence short, erect, yellowish; apices emarginate, the outer angle dentiform. Abdomen shining, sparsely pubescent. Legs slender, sparsely clothed with erect, yellowish hairs; femora not spinose. Length $15.5 \mathrm{~mm}$; breadth $2.75 \mathrm{~mm}$.

Holotype female, and allotype male, taken at Punta Gorda, British Honduras, June 1932, by Mr. J. J. White.

This species differs from typical Stizocera as characterized by Gounelle ${ }^{1}$ in that the femora are unarmed at the apex. In spite of this difference, $S$. aliena agrees more closely with Stizocera than with any other described genus. It may be associated in our lists with $S$. cribricolle Bates (from Mexico), from which the elongate, cylindrical prothorax, and slender, unarmed, non-clavate, non-pedunculate femora will easily separate it.

${ }^{1}$ Bull. Soc. Ent. France, 1907, p. 241. 

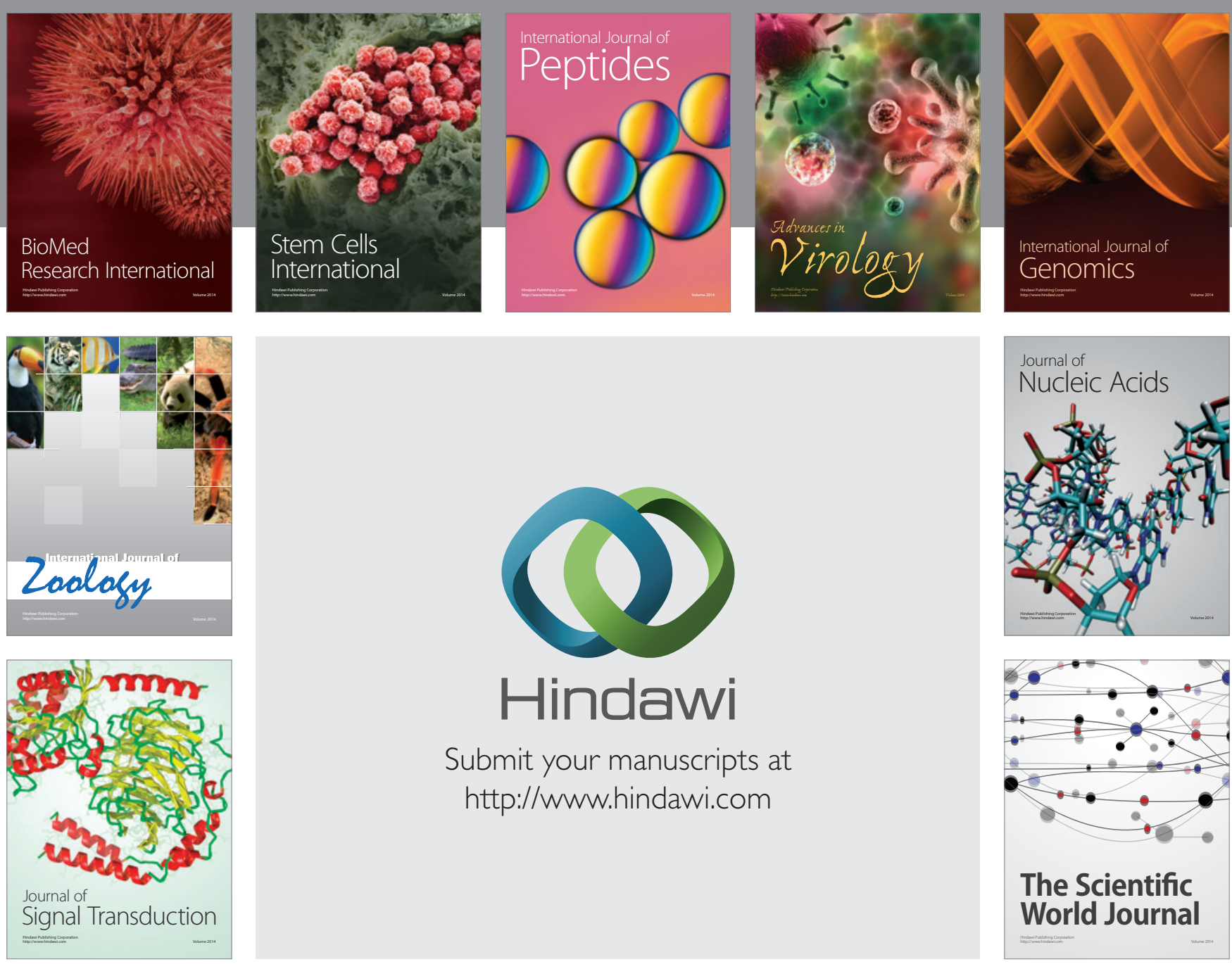

Submit your manuscripts at

http://www.hindawi.com
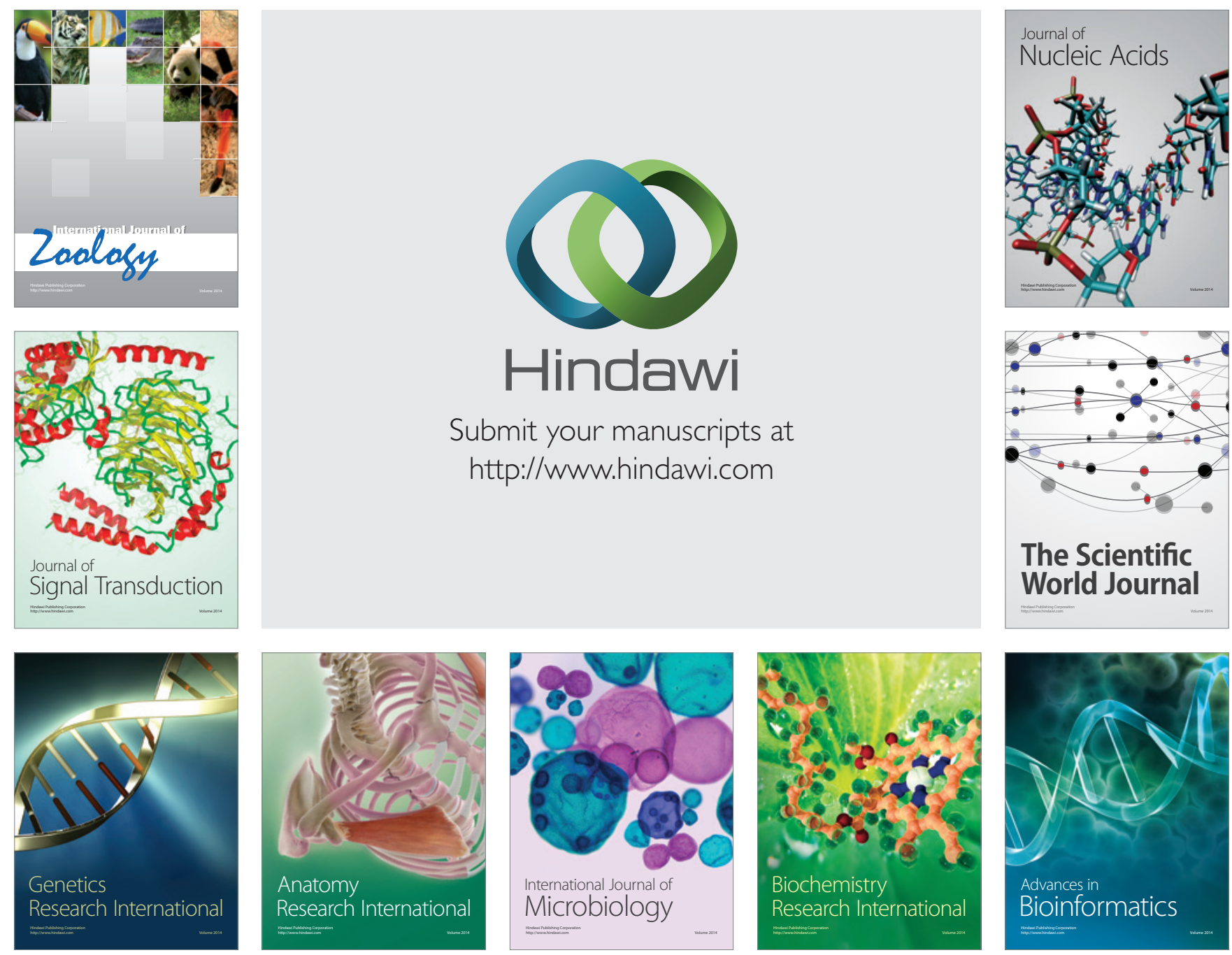

The Scientific World Journal
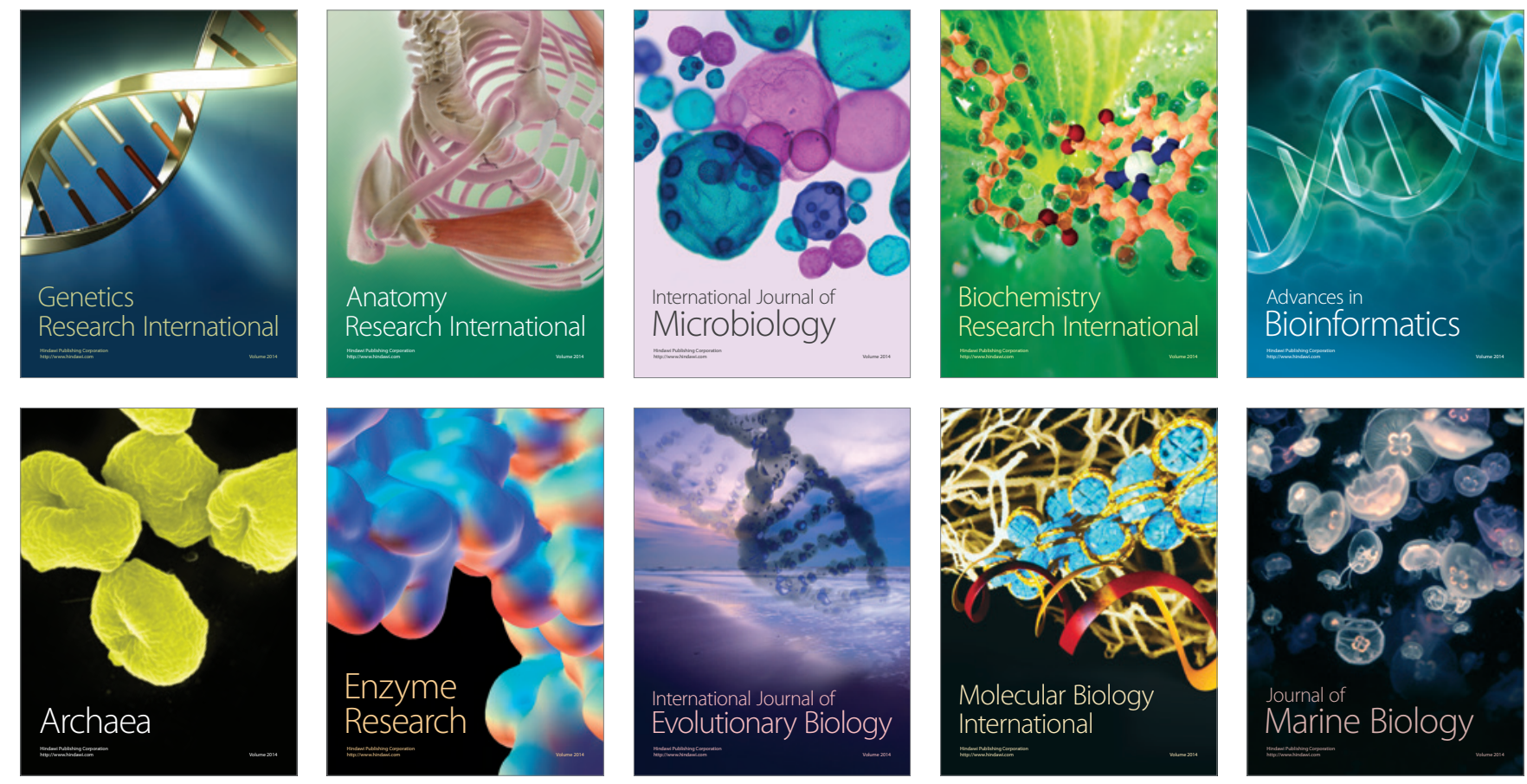